Abstracta Iranica Abstracta Iranica

Revue bibliographique pour le domaine irano-aryen

Volume 23 | 2002

Comptes rendus des publications de $\mathbf{2 0 0 0}$

\title{
Journal de voyage en Europe (1873). Traduit du persan et annoté par Bernadette Salesse, Paris, Sindbad, Actes Sud, 2000, 314 p.
}

\section{Florence Hellot}

\section{(2) OpenEdition}

Journals

Édition électronique

URL : http://journals.openedition.org/abstractairanica/35410

DOI : 10.4000/abstractairanica.35410

ISSN : 1961-960X

Éditeur :

CNRS (UMR 7528 Mondes iraniens et indiens), Éditions de l'IFRI

Édition imprimée

Date de publication : 15 mai 2002

ISSN : 0240-8910

Référence électronique

Florence Hellot, « Journal de voyage en Europe (1873). Traduit du persan et annoté par

Bernadette Salesse, Paris, Sindbad, Actes Sud, 2000, 314 p. », Abstracta Iranica [En ligne], Volume 23 |

2002, document 156, mis en ligne le 08 février 2010, consulté le 25 septembre 2020. URL : http:// journals.openedition.org/abstractairanica/35410; DOI : https://doi.org/10.4000/abstractairanica. 35410

Ce document a été généré automatiquement le 25 septembre 2020.

Tous droits réservés 
Journal de voyage en Europe (1873). Traduit du persan et annoté par Bernadette Salesse, Paris, Sindbad, Actes Sud, 2000, 314 p.

Florence Hellot 
Le souverain qājāar, Nāṣer al-Dīn Šāh, est à l'honneur : après le livre que lui a consacré le professeur 'Abbās Amānat (Pivot of the Universe, Nasir al-Din Shah Qajar and the Iranian Monarchy 1831-1896) en 1997, quelques parties des récits de voyages de Nāṣer al-Dīn Šāh sortent à la fois en persan et en français. On admire ici, dans le récit traduit en français, la manière dont Bernadette Salesse a su restituer la simplicité avec laquelle le souverain rend compte de ce qu'il voit. Il semble la plupart du temps très détaché de ce qu'il observe à tel point qu'il donne parfois l'impression de faire parler son double. Les pages où il prend parti, s'étonne ou s'enthousiasme, sont rares. On remarque ainsi le jugement qu'il porte sur l'Angleterre "qui vient en tête des autres nations». La manière dont il présente les Persans ne laisse pas d'étonner: n'en vient-il pas à proposer au baron de Rotschild, qu'il rencontre à Paris, d'acheter un territoire pour y rassembler tous les juifs et il lui assure qu'il protège « tous les étrangers qui habitent en Perse »! Comme si les Persans israélites étaient étrangers en Perse! A toute personne désireuse de mieux connaître la personnalité de Nāṣer al-Dīn Šāh, la lecture de ce journal est donc particulièrement conseillée. On regrette peut-être la faiblesse de la présentation historique du long règne de Nāsser al-Dīn Šāh (1848-1896). L'essor des écoles et l'apparition des journaux auraient mérité plus de développements que les cinq lignes de la page 18. On regrette aussi de ne pas voir citées la concession des Tabacs et la réaction qu'elle a suscitée au sein de la population de Perse : face à l'abandon par Nāṣer al-Dīn Šāh d'une partie des richesses de son pays aux étrangers, c'était à la fois un signe de la montée de l'opinion publique en Perse et les prémisses de la révolution constitutionnelle.

\section{INDEX}

Thèmes : 4.2.1. Safavides et Qâjârs

\section{AUTEURS}

\section{FLORENCE HELLOT}

CNRS - Paris 